\title{
Understanding the Corporate Values of Islamic Commercial Banks with the Theory of MM Preposition and David Durand in Capital Structure Theory
}

Difa Tsaniya Nafhanti, ${ }^{1}$ \& Darmawan ${ }^{2}$

Sunan Kalijaga State Islamic University Yogyakarta

E-mail: difatsanaf@gmail.com \& darmawan@uin-suka.ac.id

\begin{abstract}
This study aims to understand the value of Islamic public bank companies registered at OJK during 2013-2017. The used approach is the capital structure theory of MM preposition and David Durand. The used analytical method in this study is panel data regression analysis with the Random Effect Model. The study results show that the tax rate, profitability, and cost of capital simultaneously affect Islamic commercial bank companies' value. Partially, tax rates and profitability affect the value of Islamic commercial bank companies. The cost of capital does not affect the value of Islamic commercial bank companies. This study proved that the prevailing MM preposition capital structure theory is MM prepositions without tax in companies based on institutional ownership, mainly Islamic commercial banks. This study also succeeded in proving that the theory of David Durand's capital structure was proven. The cost of capital variables become influential when the company is divided into two based on institutional ownership.
\end{abstract}

Keywords. Corporate Values, Capital Structure Theory

\section{INTRODUCTION}

The dominance of the sharia banking sector in the Indonesian financial system is reflected in the magnitude of banking assets far greater than the assets of other financial institutions. The Financial Services Authority (OJK) published that currently, Islamic banking controls Indonesia's financial assets by $(72 \%)$. The assets of other financial institutions are still far below banking assets such as Islamic insurance (2\%), Syariah IKNB (6\%), Sukuk (16\%), and Sharia Mutual Funds (4\%).

Given the importance of the function and role of Islamic banking in Indonesia, the banking sector needs to improve its performance to create a clean and efficient banking system with Islamic principles. In order to find out the success of a Bank's performance, it can be seen that its financial performance is reflected in the published financial statements. One of them can be seen from the value of the company.

Company value describes as the investor's perception of the company, which is often associated with stock prices, as the current stock price reflects investors' assessment of the company in the future. If the company makes a wrong decision, the stock price will go down. Therefore, management aims to make decisions that can increase stock prices because this will generate wealth for shareholders, thus increasing the company's value (Brigham and Houston, 2006). However, in this study, company value is proxied by book value as some Islamic commercial banks have not made Initial Public Offerings (IPOs). Thus, according to a book by Hermanson (1987), value can be calculated using total assets minus liabilities (debt).

Corporate value is influenced by tax rates, supported by MM's theory with taxes (1958), which states that the use of debt will increase the company's value by including corporate income tax. This follows Lawi's (2016) research, which explains the level of debt and tax benefits of a bank having a positive relationship. Therefore, Islamic commercial banks have the motivation to reduce the tax that must be paid, namely by increasing debt.

In addition, the success of a bank's performance can be seen from its ability to earn profits, or commonly called profitability. Profitability is one of the essential indicators in measuring the performance of a bank. Good profitability will support the company's operations and play a significant role for stakeholders, such as the community, government, employees, creditors, and other 
related parties. Good profitability also supports the welfare of stakeholders, and it will also be guaranteed.

Profitability can be proxied by the ratio of Return on Assets (ROA). ROA focuses on the ability of banks to earn profits in the overall operational process of the company. The level of bank profitability is more often measured using ROA. According to Kasmir (2014) states the measure of profitability used is Return On Equity (ROE) for companies in general and Return On Assets (ROA) in the banking industry.

According to the latest Islamic Banking Statistics from the Financial Services Authority (2017), the Islamic banking industry already has a network of thirteen Islamic Commercial Banks (BUS), 34 Islamic Business Units (UUS), and 104 BPRS. Based on Law No. 21 of 2008, Islamic Commercial Banks are Islamic Banks that provide services in payment traffic. The following graph depicts the data of the Islamic Commercial Bank ROA for the period 2013-2017.

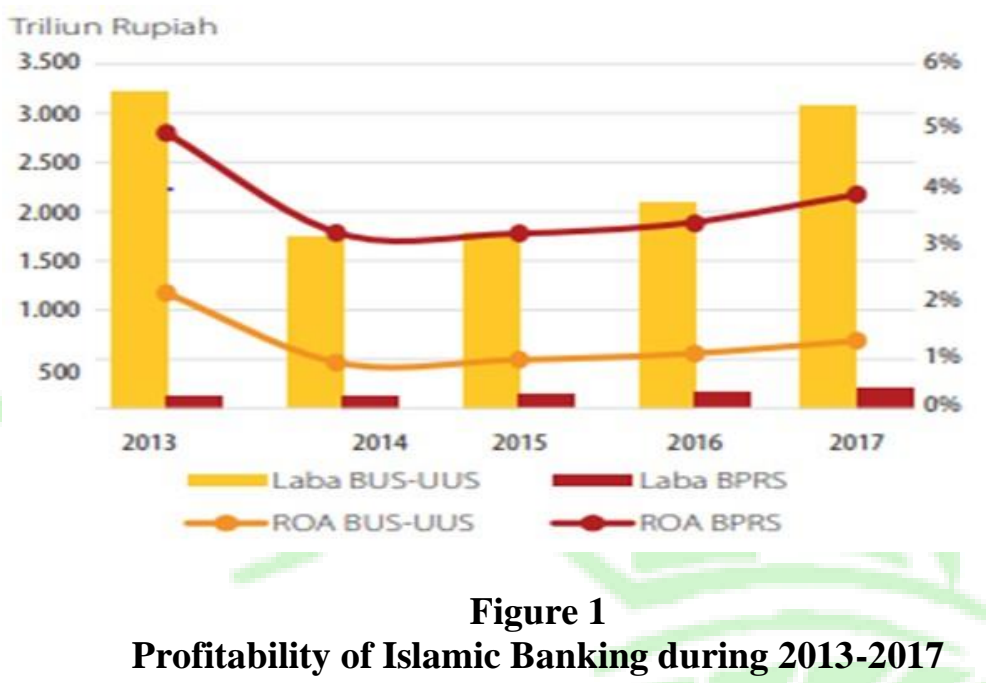

According to Bank Indonesia Circular Letter No.9 / 24 / Dpbs in 2007, Bank Indonesia sets a standard ROA of $1.5 \%$. ROA above the standard criteria set by BI has a very high management ability to manage assets in increasing revenue and reducing costs.

The diagram of the average profitability of Islamic commercial banks in Indonesia during 20132017 is contained in the Financial Services Authority Islamic banking statistics. It shows that there was a sharp decline from 2013 to 2014. However, from 2014 to 2017, there was an increase. The ups and downs of ROA are influenced by net profit margins and total assets turnover because if low ROA is caused by low-profit margins caused by low total assets turnover (Kasmir, 2014). Some banks have ROA that tend to be below the standard set by BI, which is below $1.5 \%$.

Banks that have profitability below the standards set by Bank Indonesia and experience a decline can be a problem for banks. This is as stipulated in Bank Indonesia Regulation No.9 / 1 / PBI / 2007 that "Banks that violate the rules on bank soundness will be subject to administrative sanctions including: written warning, suspension of business activities, recording of management or shareholders in a banned list." Therefore, each bank must maintain and increase the profitability of its business. Thus, it does not violate the stipulated rules and does not get sanctions.

Meanwhile, the level of cost of capital used that the company must consider the level of use of capital costs as a whole. Therefore, the costs of each source will be varied. Thus, to determine the company's capital cost as a whole needs to calculate the weighted average cost of various sources of funds. The concept of capital costs is intended to determine the real cost of capital use of each source of funds and then determine the average cost or commonly called the weighted average cost of capital (WACC) (Indra Setyawan, 2010). 
Determination of different capital costs, of course, will produce different company values. Therefore, it is necessary to analyze whether there is an influence between the cost of capital and the maximum company value. The theory of Duran (1952) explains that companies have an optimal capital structure when the maximum firm value or capital structure makes the average cost of capital a minimum. In other words, the company's value has increased to a certain point that there is an optimal capital structure and then decreases, so that it can be said that the cost of capital affects the value of the company. Based on the theory and research stated above, the cost of capital influences the fluctuation of the company's value.

According to the background of the study above, the problem formulation can be drawn as follows: does tax, profitability, and cost of capital affect the value of Islamic bank companies?

Based on the formulation of the problem and the purpose of the research, this research is expected to be able to provide the following benefits:

1) Academically

This research is expected to be a reference material for further research as it is possible to have other variables that can affect the value of Islamic commercial bank companies.

2) Islamic Commercial Banks

It is expected that the results of this study can be used as consideration for Islamic Commercial Banks in making decisions on policies related to financial issues, including funding. This research can also be used as input in improving the financial performance of Islamic Commercial Banks to continue surviving and competing in the banking industry with national and international conditions.

3) Community

Hopefully, the results of this study can provide information on the condition of Islamic Commercial Banks in Indonesia, especially for third parties, as it can be used as input in making decisions when investing. The condition can be known early.

\section{LITERATURE REVIEW}

\section{THEORETICAL FOUNDATION}

\section{a. Capital Structure Theory of MM Preposition}

Franco Modigliani and Merton H. Miller, in his article entitled The Cost of Capital, Corporate

Finance and Theory of Investment in 1958, give the assumption as follows:

1. The company owns all physical assets.

2. The capital market is without friction. There are no corporate or personal income taxes. Securities can be bought or sold at no cost and instantly, and there are no bankruptcy fees.

3. Companies can only issue two types of security, risk of equity and risk of free debt.

4. Both individuals and companies can borrow or lend at risk-free interest rates.

5. Investors have homogeneous expectations towards the flow of company profits in the future.

6. There is no growth, so all cash flows are eternal.

7. All companies can be classified into one of several "equal return classes" so that the profits on the shares of all companies in the level are comparable to and perfectly correlated with all other companies in the level (Megginson, 1997).

\section{1) The MM Approach without Tax Theory}

\section{Proposition I:}

Company value is a capitalization of net operating profit (EBIT / earnings before interest and tax) or profit before interest and tax with a constant capitalization rate following the company's level of risk. The value of companies that do not have debt is the same as that of companies with debt.

This concept also argues that the company's capital structure does not affect the value of the company. In addition, the weighted average cost of capital equals the cost of equity.

Proposition II: 
In this proposition, MM-Theory argues that the cost of equity for companies with debt results from the number of equity costs for companies that do not have debt. That pays company risk at a certain level with the risk of the company's size depending on the difference between costs equity and cost of debt and the amount of the used debt.

Preposition III:

In this preposition, MM-Theory discusses the new investments made will increase the value of the company. The company's value must increase at a minimum by the value of the project investment.

All propositions proposed by MM-Theory clearly state that the value of a company does not depend on the capital structure.

\section{2) Theory of MM's Approach to Tax}

Preposition I:

The value of a company with debt will increase as much as the saved tax (Tax-Shield). Preposition II:

Corporate equity costs that have debt will increase as much as debt used, but the cost of equity is less than equity with no tax. It means that the tax has a reduction effect on the cost of company equity. Taxes provide savings to companies in increasing company value.

Preposition III:

In this preposition, MM-theory suggests that the carried out internal rate of return of an investment project must be greater than the cost of equity minus the tax portion at the cost of equity use of funds.

\section{b. David Durand Capital Structure Theory}

Financial structure theory is associated with the company's value, firstly developed by David Duran in 1952 in his article entitled "Cost of Debt and Equity Funds for Business: Trend and Problems of Measurement." Duran assumes that corporate tax is zero. Furthermore, the value of the company can be seen with three approaches.

The first approach, namely the Net Profit Approach. In this approach, the cost of equity and debt is considered constant to increase debt. If to and kd are constant, the greater the amount of debt used, the WACC (ko) is smaller because kd is always lower than to. The value of the company increases when using more debt.

The second approach, namely the Net Operating Income Approach. In this approach, investors have different reactions to companies that experience much debt. The cost of debt is constant. Nevertheless, the greater use of debt seen by the owners of their capital increases the company's risk, thus increasing the cost of equity. Consequently, WACC has not changed, and capital structure decisions have become insignificant.

The third approach is the traditional approach. The company has an optimal capital structure when the maximum corporate value or capital structure makes the average cost of capital a minimum. This event can occur because it is assumed that the company's risk does not experience changes to a certain capital structure or certain leverage. The WACC will initially go down and, after certain leverage, the level will rise. In other words, the company's value has increased to a certain point, there is an optimal capital structure, and then decreases.

According to David Durand, the approach is the opposite of the net income approach with no tax. In this approach, the WACC remains constant; this postulates that the market analyses the entire company, and the discount has nothing to do with the debt/equity ratio. If tax information is provided, it states that the WACC reduces the increase in debt financing, and its value will increase.

\section{c. Profitability}

The values of profitability are reflected in the following Qur'an, Al An'am: 141:

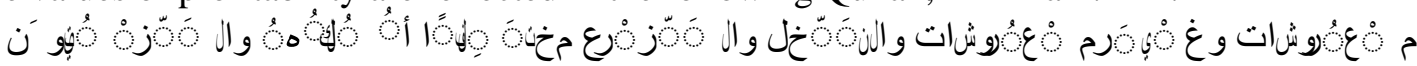

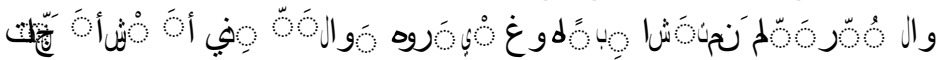

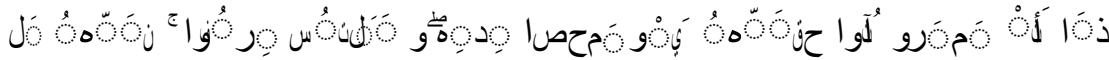

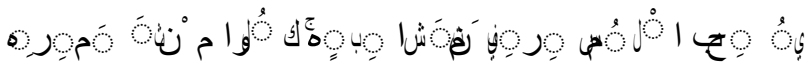

And He it is who causes gardens to grow, [both] trellised and untrellised, and palm trees and crops of different [kinds of] food and olives and pomegranates, similar and dissimilar. Eat of 
[each of] its fruit when it yields and gives it is due [zakah] on the day of its harvest. Furthermore, be not excessive. Indeed, He does not like those who commit excess.

Various ratios can measure company profitability. Nevertheless, this study only uses the ratio of return on assets. Return on Assets is the ability of the average activity in generating earnings before tax. The magnitude of the results of this calculation shows how strong the company's ability to generate profits available to ordinary shareholders with all of their acquired assets. ROA can be calculated using the formula: $\mathrm{ROA}=$ (net profit before tax) / (Total Assets) X 100\%.

\section{PREVIOUS RESEARCHES}

Hari Sulistyo (2017) conducted research entitle Analysis of Capital Structure Against WACC and WACC Analysis of Company Values. The research objects are PT HM Sampoerna Tbk, PT Gudang Garam Tbk, and PT Bentoel Investama Tbk. The research method used was a comparative descriptive method, with a population of all cigarette companies listed on the IDX, with three cigarette companies (PT HM Sampoerna Tbk, PT Gudang Garam Tbk, and PT Bentoel Investama Tbk). The data used are financial statement data for the period 2009-2013. The sampling technique is purposive sampling. Researched variables are stock price, DER, and WACC. The study results indicate that the proportion of capital structure (DER) influences the WACC. In addition, the proportion of WACC influences company value which is proxied by the stock price.

Ayu Sri Mahatma Dewi and Ary Wirajaya (2013) conducted research entitle The Influence of Capital Structure, Profitability and Company Size on Firm Value. The object of research was in manufacturing companies on the IDX. The method in determining the sample is purposive sampling. Seventy-one manufacturing companies met the criteria. The population in this study is a manufacturing company on the stock exchange in 2009-2011. This study uses multiple linear regression analysis. The study results concluded that 1) the capital structure has a negative and significant effect on firm value, 2) profitability has a positive and significant effect on firm value, 3 ) the company's size does not affect the firm's value.

Muhammad Shadap Abdul Sattar (2015) researched a topic and title his research with Cost of Capital - The Effect to the Firm Value And Profitability; Empirical Evidences in Case of the Textile Sector of KSE 100 Index. The research objects are the textile sector: Nishat Mills Limited, Kohinoor Textile Mills Limited, Colgate Palmolive (Pakistan) Limited, Bata Pakistan Limited. This study uses panel data regression analysis. The study results indicate a significant impact from the Weighted Average Capital Cost of the Company and Asset Returns. There is a positive influence between Company Size and Asset Returns if any changes occur in the Independent Variable except for one variable, namely WACC. WACC harms Company Value and Asset Returns. Furthermore, any changes in the WACC can affect the return of company assets.

Thinking Framework

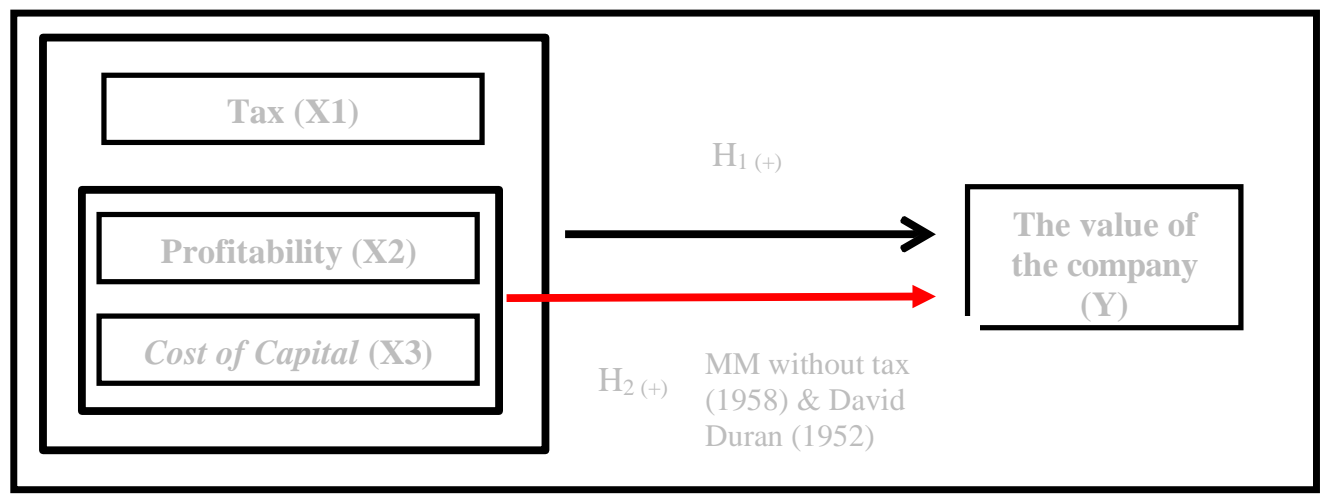

Figure 2

Thinking Framework

\section{Hypothesis}



as follows:

Based on the analysis of the theory and previous research, the research hypothesis can be drawn

1) Effect of Tax Levels on Corporate Values of Islamic Commercial Banks

Based on MM's theory with taxes (1958), by including corporate income tax, debt will increase the company's value. In income tax conditions, companies with leverage will have a higher value than companies without leverage. The increase in the company's value occurs as an effect of interest payment on a debt is a tax deduction. Therefore, the operating profit that flows to investors is getting bigger.

2) Influence of Profitability on Corporate Values of Sharia Commercial Banks

The theory of capital structure from Modigliani Miller's approach without tax (1958) states that company value is a capitalization of net operating profit (EBIT) or profit before interest and tax with a constant capitalization rate (ko) following the company level of risk. The concept means that company value is influenced by profitability. The following statement is supported by Signaling Theory, Bhattacarya (1979), which explains that high profitability shows good company prospects so that investors will respond positively and increase the company's value.

3) Effect of Cost of Capital on Corporate Values of Islamic Commercial Banks

Duran, 1952 explains that the company has an optimal capital structure when the maximum company value or capital structure makes the average cost of capital a minimum.

The hypothesis can be taken from the explanation above as follows:

1. H0: Variables X1, X2, X3 affect $Y$

H1: Variables $X 1, X 2, X 3$ do not affect $Y$

2. H0: Variable $X 2, X 3$ affects $Y$

H1: Variable X2, X3 does not affect $Y$

\section{RESEARCH METHODS}

In this study, the data used is included in the secondary data type. Secondary data in this research are data in the form of numbers presented and published in financial statements that can be accessed on the web of Islamic Commercial Bank companies during the year 2013-2017.

The research sample used the purposive sampling method to get a representative sample with the specified criteria. The research will use only eleven Sharia Commercial Banks as the research sample.

The method used in this study is a data panel regression analysis model. In analyzing panel data models, three approaches are used in estimating panel data regression models, namely Common Effect Model, Fixed Effect Model, and Random Effect Model.

\section{DISCUSSION}

During 2013-2017, the Financial Services Authority (OJK) had twelve Islamic Commercial Banks. After a purposive sampling method, there was a sample of eleven Islamic banks based on ownership consisting of seven private banks and four state-owned banks. Then, 55 financial statements were obtained. These data include large data types and have met the minimum amount of data to be studied.

\section{Tabel 1}

Object of research

\begin{tabular}{cl}
\hline No & \multicolumn{1}{c}{ Company name } \\
\hline 1. & Bank Muamalat Indonesia (BMI) \\
2. & Bank Victoria Syariah (BVS) \\
3. & BRI Syariah (BRIS) \\
4. & BPD Jawa Barat Banten Syariah (BJBS) \\
5. & BNI Syariah (BNIS) \\
6. & Bank Syariah Mega Indonesia (BMS) \\
7. & Bank Panin Syariah (BPS) \\
8. & Bank Syariah Bukopin (BSB) \\
\hline
\end{tabular}


\begin{tabular}{ll} 
9. & Bank Syariah Mandiri (BSM) \\
10. & BCA Syariah (BCAS) \\
11. & Maybank Syariah (MBS) \\
\hline
\end{tabular}

1) Effect of Tax, Profitability, and Cost of Capital on Corporate Values of Islamic Commercial Banks

Panel data was tested by panel data testing with random effect models to determine the effect of profitability, tax rate, and cost of capital on the value of Islamic commercial bank companies during 2013-2017.

Tabel 2 Estimated Results Using the Random Effect Model

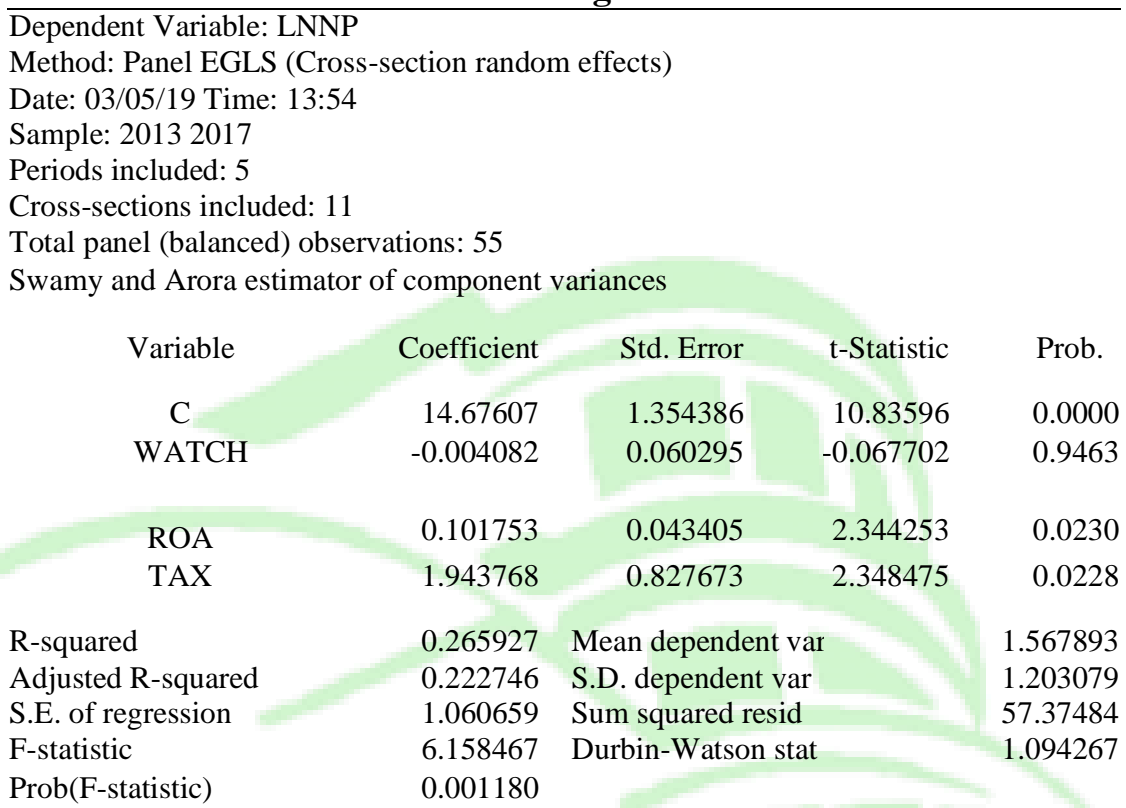

The regression results in Table 2 can be written as follows:

Ln Company Value: $14.6760+1.9437 \mathrm{X}_{1}+0.01017 \mathrm{X}_{2}-0.0040 \mathrm{X}_{3}$

Hypothesis testing was done through 3 kinds of tests:

\begin{tabular}{lr}
\multicolumn{1}{c}{ Tabel 3 F-Statistic Test Result } \\
\hline F-statistic & 6.158467 \\
Prob(F-statistic) & $\underline{0.001180}$ \\
\hline
\end{tabular}

Table 3 shows F-statistics of 6.15 with a probability of 0.0011 . The probability of 0.0011 is less than $\alpha(0.05)$, which means that all independent variables together $(\mathrm{X} 1, \mathrm{X} 2, \mathrm{X} 3)$ can affect the dependent variable (Company Value).

Table 4 Results of the Determination Coefficient $\left(\mathbf{R}^{2}\right)$

\begin{tabular}{ll}
\hline R-squared & 0.265927 \\
Adjusted R-squared & $\underline{0.222746}$ \\
\hline
\end{tabular}

Table 4 shows the coefficient of determination (Adj. $\mathrm{R}^{2}$ ) of 0.2227 . The following condition means that the independent variable can explain the dependent variable by $22.27 \%$, while the remaining $77.73 \%$ is explained by other variables not included in the research.

Tabel 5 Test Results t (t-test) 


\begin{tabular}{crrrr}
\hline Variable & Coefficient & Std. Error & t-Statistic & Prob. \\
\hline C & 14.67607 & 1.354386 & 10.83596 & 0.0000 \\
WATCH & -0.004082 & 0.060295 & -0.067702 & 0.9463 \\
ROA & 0.101753 & 0.043405 & 2.344253 & 0.0230 \\
PAJAK & 1.943768 & 0.827673 & 2.348475 & 0.0228 \\
\hline
\end{tabular}

Table 5 used a $95 \%$ confidence level $(\alpha=0.05)$ and result as follows:

a. The tax rate ratio $\left(\mathrm{X}_{1}\right)$ has a regression coefficient of 1.9437 and the t-value of statistics of 2.3484 with a probability of 0.0228 . The probability value is smaller than $\alpha(0.0228<0.05)$. It means that the tax rate variable partially has a significant positive effect on the value of Islamic commercial bank companies.

b. The profitability ratio $\left(\mathrm{X}_{2}\right)$ has a regression coefficient of 0.1017 , and the $t$ value of statistics is 2.3442 , with a probability of 0.0230 . The probability value is smaller than $\alpha(0.0230<0.05)$. It means that the profitability ratio variable partially has a significant positive effect on the value of Islamic commercial bank companies.

c. The cost of capital $\left(\mathrm{X}_{3}\right)$ ratio has a regression coefficient of -0.0040 and a statistical $t$ value of -0.0677 with a probability of 0.9463 . If the probability value is greater than $\alpha(0.9463>0.05)$, the variable cost of capital ratio partially does not affect the value of Islamic commercial bank companies.

Thus, the tax rate and profitability variables partially significantly affect the value of Islamic commercial bank companies in 2013-2017. Other variables show differently. The cost of capital partially does not affect the value of Islamic commercial bank companies in 2013-2017.

\section{2) Effect of Profitability and Cost of Capital on Corporate Values of Islamic Commercial Banks}

Panel data was tested by testing panel data with a random effect model to determine the effect of profitability and cost of capital on the value of Islamic commercial bank companies in 2013-2017.

\section{Tabel 6 Estimated Results Using the Random Effect Model}

Dependent Variable: LNNP

Method: Panel EGLS (Cross-section random effects)

Date: 03/05/19 Time: 16:14

Sample: 20132017

Periods included: 5

Cross-sections included: 11

Total panel (balanced) observations: 55

Swamy and Arora estimator of component variances

$\begin{array}{crccc}\text { Variable } & \text { Coefficient } & \text { Std. Error } & \text { t-Statistic } & \text { Prob. } \\ \text { C } & 15.21836 & 1.556956 & 9.774433 & 0.0000 \\ & - & & & \\ & 0.03 & & & \\ \text { WATCH } & 174 & & & 0.6155 \\ \text { ROA } & 4 & 0.062825 & -0.505269 & 0.0009\end{array}$

Effects Specification

S.D. Rho 
Idiosyncratic random

1.087439

0.0429

\begin{tabular}{llll} 
& Weighted Statistics & \\
R-squared & 0.197224 & Mean dependent var & 1.428643 \\
Adjusted R-squared & 0.166348 & S.D. dependent var & 1.184858 \\
S.E. of regression & 1.081829 & Sum squared resid & 60.85842 \\
F-statistic & 6.387604 & Durbin-Watson stat & 1.352102 \\
Prob(F-statistic) & 0.003307 & & \\
\hline
\end{tabular}

The regression results in Table 6 can be written as follows:

Ln Company Value: $15,2183+0,1464 \mathrm{X}_{1}-0,0317 \mathrm{X}_{2}$

Hypothesis testing is done with 3 tests:

\begin{tabular}{lr}
\multicolumn{2}{c}{ Tabel 7 F-statistic Test Results } \\
\hline F-statistic & 6.387604 \\
Prob(F-statistic) & 0.003307
\end{tabular}

Table 4.7 obtains $F$ statistics of 6.38 with a probability of 0.0033 . The probability of 0.0033 is less than $\alpha(0.05)$, which means that all independent variables $(\mathrm{X} 2, \mathrm{X} 3)$ can affect the dependent variable (Company Value).

Table 8 Results of the Determination Coefficient $\left(\mathbf{R}^{2}\right)$

\begin{tabular}{ll}
\hline R-squared & 0.197224 \\
Adjusted R-squared & $\underline{0.166348}$ \\
\hline
\end{tabular}

Table 8 shows the coefficient of determination is obtained (Adj. $R^{2}$ ) in the number of 0.1663 . This means that the independent variable can explain the dependent variable by $16.63 \%$, while the remaining $83.37 \%$ is explained by other variables not included in the study.

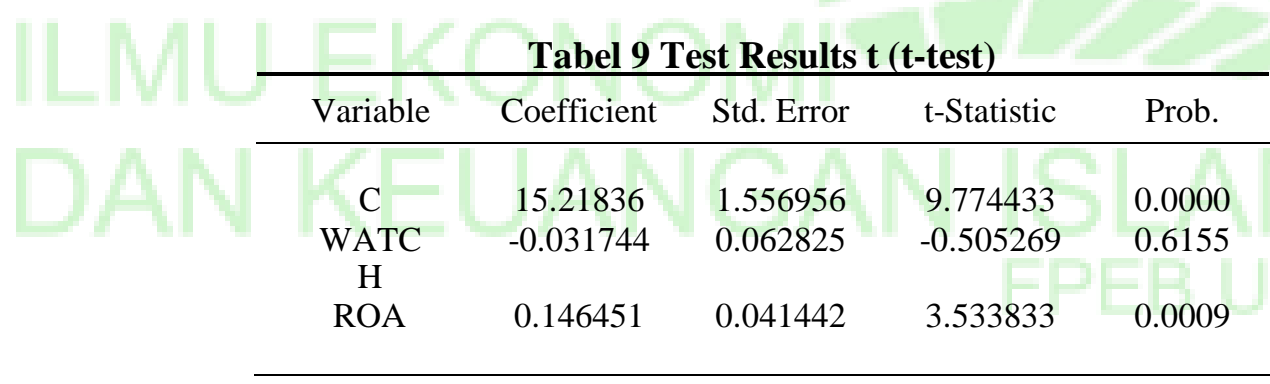

Table 4.9, using a 95\% confidence level $(\alpha=0.05)$, shows the results as follows:

a. The profitability ratio $\left(\mathrm{X}_{2}\right)$ has a regression coefficient of 0.1464 and an at-value of statistics of 3.5338 . The probability value is smaller than $\alpha(0,0009<0,05)$, whereas the profitability ratio variable partially has a significant positive effect on the value of Islamic commercial bank companies.

b. The cost of capital $\left(\mathrm{X}_{3}\right)$ ratio has a regression coefficient of -0.0317 and a statistical $t$ value of -0.5052 with a probability of 0.6515 . The probability value is greater than $\alpha(0.6515>0.05)$. It means that the cost of capital variable partially does not affect the value of Islamic commercial bank companies.

It could be concluded that profitability variables partially have a significant effect on the value of Islamic commercial bank companies in 2013-2017. While the cost of capital variable partially does not affect the value of Islamic commercial bank companies in 2013-2017.

Based on the results of panel analysis of random effect models, the tax rate variable has a significant positive effect on the value of Islamic commercial bank companies. This is because the 
regression coefficient value is 1.9437 , and the $t$ value of statistics is 2.3484 , with a probability of 0.0228 . The probability value is smaller than $\alpha(0.0228<0.05)$. It means that the tax rate variable partially has a significant positive effect on the value of Islamic commercial bank companies.

This is in line with MM's theory with taxes (1958), stating that by including corporate income tax, the use of debt will increase the company's value. In income tax conditions, companies with leverage will have a higher value than companies without leverage. The increase in the value of the company occurs because the interest payment on a debt is a tax deduction. Therefore the operating profit that flows to investors is getting bigger. So the hypothesis is accepted.

Profitability is one of the important indicators in measuring the performance of a bank. Good profitability can support the company's operations. Profitability can be proxied by ROA (Return On Asset).

Based on the panel random effect model data analysis results, the variable profitability ratio has a significant positive effect on the value of Islamic commercial bank companies. It happens as the obtained regression coefficient value is 0.1017 and the $t$ value of statistics is 2.3442 with a probability of 0.0230 , and the probability value is smaller than $\alpha(0.0230<0.05)$. The average profitability ratio of sharia commercial banks during 2013-2017 was -0.2012 or $-20.12 \%$. This average yield is still below the standard set by Bank Indonesia, which is $1.5 \%$.

These test results follow the second hypothesis, which states that the profitability ratio has a significant positive effect on the value of Islamic commercial bank companies. If the probability is high, it can positively signal to investors that the company produces in favorable conditions. This is an attraction for investors to own company shares. Thus, increasing the value of the company.

The cost of capital represents the actual costs that the company incurs to obtain funding. The funding source itself can come from 2 types of sources: equity in ordinary shares, preferred stock, and retained earnings. While the second source of funding, namely debt or long-term debt.

Based on the results of panel analysis of the random effect model, the variable cost of capital does not affect the value of Islamic commercial bank companies. It happens as the regression coefficient value is -0.0040 and the statistical $t$ value is -0.0677 with a probability of 0.9463 . The probability value is greater than $\alpha(0.9463>0.05)$.

The theory (Duran, 1952) explains that the company has an optimal capital structure when the maximum company value or capital structure makes the average cost of capital a minimum.

The following condition can be explained as if the WACC is high; the equity payment is also high. A high WACC requires companies to be careful in investing, as it will demand high returns. The lower the WACC value, the better for the company, as the company's responsibility provides low returns to shareholders.

Yet, this study found that institutional ownership affects the cost of capital or the value of Islamic commercial bank companies. This is proven when separating banks based on institutional ownership, namely government-owned Islamic public banks and private-owned Islamic public banks. The following is a test table for the results of $\mathrm{R}^{2}$ of government-owned and private-owned Islamic commercial banks.

\section{Tabel 10 Testing of Regression Results of Government-Owned Islamic Banks}

Dependent Variable: LNNP

Method: Panel EGLS (Cross-section random effects)

Date: 03/05/19 Time: 16:25

Sample: 20132017

Periods included: 5

Cross-sections included: 4

Total panel (balanced) observations: 20

Swamy and Arora estimator of component variances

Variable Coefficient Std. Error t-Statistic Prob. 
Cross-section random Idiosyncratic random

R-squared Adjusted R-squared S.E. of regression F-statistic Prob(F-statistic)

$\begin{array}{rrrr}11.58437 & 0.146097 & 79.29254 & 0.0000 \\ -0.105537 & 0.009947 & -10.61029 & 0.0000 \\ & & & \\ -0.582555 & 0.023244 & -25.06242 & 0.0000 \\ 0.854346 & 0.422275 & 2.023199 & 0.0601\end{array}$

Effects Specification

S.D. Rho

Weighted Statistics

0.439013 Mean dependent var $\quad 11.54405$

0.333828 S.D. dependent var $\quad 2.439241$

1.990893 Sum squared resid $\quad 63.41846$

4.173722 Durbin-Watson stat $\quad 0.745836$

0.023153

Unweighted Statistics

R-squared

0.439013 Mean dependent var

11.54405

Sum squared resid

63.41846 Durbin-Watson stat

0.745836

\section{Tabel 11 Testing of Regression Results of Private Islamic Sharia Banks}

Dependent Variable: LNNP

Method: Panel EGLS (Cross-section random effects)

Date: 03/05/19 Time: $16: 24$

Sample: 20132017

Periods included: 5

Cross-sections included: 7

Total panel (balanced) observations: 35

Swamy and Arora estimator of component variances

\begin{tabular}{c|rrrr} 
Variable & Coefficient & Std. Error & t-Statistic & Prob. \\
C & 16.84271 & 1.330911 & 12.65502 & 0.0000 \\
WATC & 0.123283 & 0.054276 & 2.271410 & 0.0302 \\
H & 2.247503 & 1.047984 & 2.144596 & 0.0399 \\
ROA & - & & & \\
& 0.41 & & & \\
& 287 & & & \\
PAJAK & 1 & 0.652321 & -0.632926 & 0.5314
\end{tabular}

Effects Specification

S.D. Rho

Cross-section random

Weighted Statistics

R-squared

0.314722 Mean dependent var

2.706886

Adjusted R-squared

0.248404 S.D. dependent var

1.556682 
Review of Islamic Economics and Finance (RIEF) Volume 2, Number 1, June 2019

\begin{tabular}{llll}
\hline F-statistic & 4.745694 & Durbin-Watson stat & 1.024331 \\
Prob(F-statistic) & 0.007747 & & \\
& Unweighted Statistics & \\
R-squared & -0.003489 & Mean dependent var & 17.22077 \\
Sum squared resid & 837.6190 & Durbin-Watson stat & 0.069046 \\
\hline
\end{tabular}


Based on the testing table, the $\mathrm{R}^{2}$ results are obtained that $\mathrm{R}^{2}$ of the state-owned Islamic banks $\mathrm{R}^{2}$ is 0.3338 or $33.38 \%$ affects the company's value, while the $\mathrm{R}^{2}$ of the state-owned Islamic banks is 0.2484 or $24.84 \%$ affects the value of the company. This is supported by research (Tendi, 2007) that the number of large shareholders has an important meaning in monitoring managerial behavior in the company. The presence of institutional ownership will be able to monitor the management team effectively and increase the company's value.

While according to research (Lestari, 2017), institutional ownership managed to increase company value, this shows that the control function of the owner is very decisive in improving the company's performance. According to Barnae and Rubin (2005), the greater the institutional ownership, the stronger the company's control. Thus, the owner of the company can control the behavior of management to act following the company's objectives, which will ultimately increase the value of the company.

This study has successfully proved that the prevailing preposition MM capital structure theory in companies, especially Islamic commercial banks, is MM without Tax preposition. It was caused as taxes have no effect when the company is examined based on institutional ownership. This study also proved that David Durand's capital structure theory was proven, the Cost of Capital variable became influential when the company was divided into two based on institutional ownership. The condition proves that institutional ownership affects the Cost of Capital or not affects the value of Islamic commercial bank companies.

\section{CLOSING}

\section{Conclusions}

Based on the previously described analysis and the factors that influence the value of the

Islamic commercial bank company, the conclusions are as follows:

1) Variable tax rates, profitability, and cost of capital simultaneously influence the value of Islamic commercial bank companies. Yet, the cost of capital does not partially affect the value of Islamic commercial bank companies.

2) Variable profitability and cost of capital simultaneously influence the value of Islamic commercial bank companies. Yet, the cost of capital does not partially affect the value of Islamic commercial bank companies.

3) Both models in this study show that the cost of capital partially does not affect the value of Islamic commercial bank companies. The study found that institutional ownership also affected the value of Islamic commercial bank companies. The greater the institutional ownership, the stronger the company's control so that the owner of the company can control the behavior of management to act following the company's objectives, which will ultimately increase the value of the company.

\section{Suggestions}

Based on the analysis of the factors described in the previous chapter that influence the value of Islamic commercial bank companies, the authors provide advice to the company, the community as customers, and the next researcher as follows:

1) Islamic commercial banks companies need to improve the quality and quality of Islamic banking products to be more interested in using products from Islamic commercial banks. 
2) In this matter, as customers, people are expected to be more aware of the advantages and advantages of Islamic banking compared to conventional banking and immediately switch to Islamic banking.

3) Further researchers are expected to add institutional ownership variables or make the institutional ownership variable a moderating variable that may affect the value of Islamic commercial bank companies.

\section{REFERENCES}

Ayu Sri dan Ary Wirajaya. 2013. Pengaruh Struktur Modal, Profitabilitas, dan Ukuran Perusahaan Pada Nilai Perusahaan. E-Jurnal Akuntansi Universitas Udayana 4.2 (2013): 358-372.

Barnae, Amir dan Amir Rubin. 2005. Corporate Social Responsibility as a Conflict Between Shareholders. Jurnal Keuangan dan Perbankan Vol. 16 No.2

Bhattacharya, S 1979." Imperfect Information, Dividend Policy and The Bird in. The Hand Fallacy " Journal of Economics. vpl.10:pp 259-27.

David Durand. 1952. Cost of Debt and Equity Funds for Business: Trends and Problems of Measurement. National Bureau of Economic Research, Conference on Research in Business Finance.

Hari Sulistyo. 2017. Analisis Struktur Modal Terhadap WACC dan Analisis WACC Terhadap Nilai Perusahaan Jurnal Volume 2 No. 012017.

Haruman, Tendi. 2007. Pengaruh Kepuutusan Keuangan dan Kepemilikan Institusional Terhadap Nilai Perusahaan (Studi Kasus Pada Perusahaan Manufaktur yang listing di BEJ). The First PPM National Conference On Management Research. Sekolah Tinggi Manajemen PPM Universitas Widayatama Bandung.

Hermanson, Roger H., Jerry R. Strawser, and Robert H. Strawser. 1987. Auditing Theory and Practice. Illinois: Irwin.

Houston, Brigham E F. 2006. Dasar-dasar Manajemen Keuangan. Jakarta: Salemba Empat.

Indra Setyawan, Apriyani Dorkas Rambu Atahau. 2010. Cost of Capital Pada Bank Mandiri Syariah Peiode 2004-2008. Jurnal Keuangan dan Perbankan, Vol. 14, No.1 Januari 2010.

Kasmir. 2014. Analisis Laporan Keuangan, Edisi Satu, Cetakan Ketujuh. Jakarta: Raja Grafindo Persada.

Lawi, M, 2016. "Analisis pengaruh ukuran perusahaan, profitabilitas, pertumbuhan penjualan, dan tingkat pajak terhadap struktur modal bank umum syariah di Indonesia tahun 2013-2014", Jurnal Pendidikan Akuntansi, vol 01, nomor 01.

Lestari. 2017. Pengaruh Kepemilikan Institusional Dan Struktur Modal Terhadap Nilai Perusahaan. Jurnal Riset Manajemen dan Bisnis (JRMB) Fakultas Ekonomi UNIAT Vol.2, S1, September 2017.:293-306.

Muhammad Shadap Abdul Sattar. 2015. Cost of Capital- The Effect on the Firm Value And Profitability; Empirical Evidences in Case of Personal Goods (Textile) Sector of KSE 100 Index. Journal of Poverty, Investment and Development

William L. Megginson. 1997. Corporate Finance Theory. Addison-Wesley: University of Georgia. 